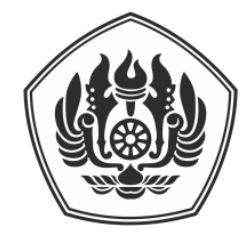

Padjadjaran Journal of International Law

ISSN: 2549-2152, EISSN: 2549-1296

Volume 3, Number 1, January 2019

\title{
The Urgency of Electronic Waste Management Regulation in International and Regional (ASEAN) Law with Environmental Protection Approach
}

\author{
Nadya Meta Puspita*
}

\begin{abstract}
The development of technology has been increasing rapidly thus almost all aspects of humans are supported by technology and electronic equipment. More electronic wastes are produced, but those could not be managed similar to the conventional wastes and do not have the same characteristics as hazardous wastes as regulated in the Basel Convention 1989 so that the Convention cannot be applied to electronic wastes management optimally. In this present time, there are still no instruments in international law regarding the management of electronic wastes, but the international community has begun to discuss this issue and argue that it is necessary to develop regulations in international and regional levels, especially in the ASEAN region. The analysis and conclusions of this research shows that the Basel Convention cannot optimally accommodate the regulation of electronic wastes management and it is necessary to establish a regulation in the form of a mechanism under the Basel Convention 1989 with regard to environmental aspects. Arrangements at the ASEAN regional level should be made by referring to the principles regulated in the mechanism and formed in a coordinative and non-coercive guideline.
\end{abstract}

Keywords: E-waste, e-waste management, environmental protection

\section{Urgensi Manajemen Limbah Elektronik dalam Hukum Internasional dan Regional (ASEAN) dengan Menggunakan Pendekatan Perlindungan Lingkungan}

\begin{abstract}
Abstrak
Teknologi semakin berkembang hampir semua aspek kehidupan manusia telah didukung oleh teknologi dengan peralatan elektronik. Produksi sampah elektronik semakin banyak, namun mereka tidak dapat dikelola seperti sampah konvensional dan juga tidak sepenuhnya memiliki karakteristik yang sama seperti sampah B3 yang telah diatur dalam Konvensi Basel 1989 sehingga Konvensi tidak dapat diterapkan pada pengelolaan sampah elektronik secara optimal. Saat ini, belum ada instrumen dalam hukum internasional mengenai pengelolaan sampah elektronik, namun masyarakat internasional sudah mulai membahas isu ini dan perlu adanya untuk mengembangkan peraturan di tingkat internasional dan regional, khususnya di ASEAN. Analisis dan kesimpulan penelitian ini memperlihatkan pengaturan dalam Konvensi Basel 1989 tidak dapat mengakomodasi secara optimal mengenai pemanfaatan sampah elektronik sehingga perlu dibuat suatu peraturan berupa mekanisme di bawah Konvensi Basel 1989 dengan memperhatikan aspek-aspek lingkungan.
\end{abstract}

PADJADJARAN JOURNAL OF INTERNATIONAL LAW Volume 3 Number 1 Year 2019 [ISSN 2549-2152] [e-ISSN 2549-1296]

* $\quad$ Researcher at Legalkeun, Jl. Ir. H. Juanda No. 84, Kota Bandung, nadyameta@gmail.com. 


\section{Regional (ASEAN) Law with Environmental Protection Approach}

Pengaturan di tingkat regional ASEAN dapat dibuat dengan mengacu pada prinsip-prinsip yang diatur dalam mekanisme tersebut namun dibentuk berupa panduan yang lebih koordinatif dan tidak memaksa.

Kata Kunci: Sampah elektronik, pengelolaan sampah elektronik, perlindungan lingkungan

\section{A. INTRODUCTION}

Along with the development of technology, it will also be in line with the production of the electronic waste. Initially, humans did not need to worry about the disturbances or dangers that resulted from pollution or environmental damage due to environmental conditions that were still sustainable because humans still believed in nature's ability to naturally cope with any damage that occurred (life sustaining system). ${ }^{1}$ This is because nature has the ability to return to its original state after having interference from outside its environment which is called resilience. ${ }^{2}$

Rapid industrial developments have resulted in irreversible pollution, which are poisonous and threaten natural ecosystems. ${ }^{3}$ Technologies are developed and innovated rapidly so that today, there are many forms of electronic devices that can facilitate our work and lifestyle. The price of electronic devices are quite affordable, making almost everyone able to use electronic devices for daily necessities. However, this might create new problems for the environment. This is because electronic waste (e-waste cannot decompose on its own, even its components contain dangerous substances. E-waste is classified as any type of electrical or electronic equipment and its parts that have been disposed of without the intention of being reused by the owner. ${ }^{4}$

Moreover, the competition for electronic device manufacturers exacerbates this situation as software manufacturers compete to continue to create new programs that demand faster and more sophisticated hardware support to operate them. This makes the use of electronic devices, especially those that use certain software with regular updates, such as cell phones, televisions, computers, tablet computers, laptops, and other electronic devices, decreasing. ${ }^{5}$ Not to mention the discourse of developing the Internet of Things (IOT) which is able to connect electronic devices and integrate them with the daily lives of users which will produce more electronic devices and their e-waste. ${ }^{6}$

The accumulation of old electronic devices will increase, either because they are out of date and the software cannot be updated, or because they are damaged and can no longer be used and thrown away by their owners. Based on data from the International Telecommunication Union (ITU), in 2016 e-waste generated an amount up to 44.7 million metric tons (Mt) and only $20 \%$ of e-waste could be recycled through a safe and proper process. ITU also stated that electronic waste estimates will increase in the coming years and reach 52.2 million $\mathrm{Mt}$ in 2021.

E-waste and its current handling might threaten sustainability, pollute and destroy the environment. This is because e-waste contains materials that are mostly categorized as hazardous and toxic materials, or which are often referred to as hazardous

\footnotetext{
M. Daud Silalahi, Hukum Lingkungan dalam Sistem Penegakan Hukum Lingkungan Indonesia, Bandung: Alumni, 2001, p. 6. Otto Soemarwoto, Ekologi, Lingkungan Hidup dan Pembangunan, Jakarta: Djambatan, 1991, p. 8. M. Daud Silalahi, Op.Cit., p. 8.

Michelle Heacock, (et.al.)., "E-Waste and Harm to Vulnerable Populations: A Growing Global Problem", Environmental Health Perspective, Vol. 124, No.5, 2016, p. 550.

Rolf Widmer (ed.), "Global Perspective on E-waste”, Environmental Impact Assessment Review, Vol. 25, 2005, p. 436-458.

Ted Saarikko, (et.al.), “The Internet of Things: Are you ready for what's coming?”, Business Horizons, Vol. 60, No. 5, 2017, p. 667.
} 
and toxic waste such as heavy metals. If ewaste is disposed of directly into open dumping, it will produce leachate (a liquid produced from waste decomposition and external water infiltration from rain) and other hazardous substances. The burning of e-waste that is carried out in an incinerator also has an impact on air pollution which produces dioxins and furans which are harmful to the environment and health. This shows that the disposal of electronic waste cannot be treated the same as other wastes.

The increasing amount of e-waste has made countries start to move to make regulations regarding e-waste and its management. Until now, countries with $66 \%$ of the world's population have been equipped with regulations regarding e-waste, but these regulations have not been implemented and implemented optimally. ${ }^{7}$ Based on these facts, there have been many countries that have seriously regulated the problem caused by e-waste, regardless of whether the regulations have or have not been implemented optimally.

\section{B. E-WASTE RELATED REGULATIONS IN INTERNATIONAL AND REGIONAL LAW}

E-waste is defined in Article 2 paragraph (1) of the Basel Convention 1989 as a substance or object that is disposed of or is forced to be disposed of or must be disposed of by the provisions of national law. Hazardous waste is defined in the Basel Convention 1989 as waste that falls into the categories listed in Annex II, unless it does not have the characteristics listed in Annex II, and waste that is not covered in that Annex but is defined as and/or is considered hazardous waste by law, domestic invitations for export, import or transit parties. Therefore, the

C.P. Baldé, (et.al.), The Global E-waste Monitor - 2017, Bonn/Geneva/Vienna: United Nations University (UNU), International Telecommunication Union (ITU) \& International Solid Waste Association (ISWA), 2017, p. 5. definition of hazardous waste in the Convention incorporates national laws so that waste that is considered hazardous in one country may not be considered hazardous in another country.

The main obligation of participants in the Basel Convention 1989 is to regulate the transfer of hazardous waste to be carried out in accordance with environmentally sound management (ESM) principles, either by countries of origin, importing countries or countries of transit. If the party concerned in the process of transferring hazardous waste cannot do so in accordance with the ESM principles, the country concerned must prohibit the sending or receiving hazardous waste. $^{8}$

If the delivery of hazardous waste will transit to a third country, based on Article 2 Paragraph (13) of the Convention, each participating country must require every person managing hazardous waste and other waste that will pass through (transit) another country to notify with written notification. Based on Article 4 Paragraph (2) letter (e) of the Convention, participating countries may not allow the export of hazardous waste to countries or groups of countries that have a pattern of economic integration or groups of developing countries that have prohibited the import of hazardous waste or if it is believed that hazardous waste it will not be managed under ESM principles.

Based on the provisions in Article 6 Paragraph (1) of the Convention, it is required that the delivery of hazardous waste must be accompanied by prior informed consent from the recipient country and the country of transit. Thus, other countries are not allowed to move their waste to countries that have implemented the ban except through special agreements. This provision is intended to

Patricia W. Birnie (et.al), International Law and the Environment, Oxford: Oxford University Press, 2008, p. 338. 


\section{Regional (ASEAN) Law with Environmental Protection Approach}

prevent the illegal trade of hazardous waste. State parties are required to implement national legal provisions that prevent and prohibit the illegal trade of hazardous waste in accordance with the provisions in Article 4 Paragraph (3) and Article 9 Paragraph (5) of the Convention which states that the illegal transfer of hazardous and other waste is an criminal act and must be prevented and penalized in accordance with the national laws of the country.

Furthermore, Article 8 of Convention states that if hazardous waste is illegally imported, then it must be returned to the country of origin. Based on Article 4 Paragraph (2) Letter (a), the countries participating in the Convention are also obliged to ensure to reduce to a minimum the regeneration of hazardous waste by taking into social, economic, and technological aspects. Article 4 Paragraph (2) Letter (b) also states that facilities for hazardous waste disposal in accordance with ESM principles must be provided near the location where the waste is generated.

Based on Article 4 Paragraph (2) Letter (c), each participating country must ensure that the party that manages hazardous waste and other wastes is to prevent pollution and if there is pollution, that party must minimize the risk, especially to human's health and the environment. Article 4 Paragraph (7) Letter (a) states that each participating country must prohibit every person from sending or disposing of hazardous waste or other waste unless the person has a permit to do so.

Apart from the Convention, there are also a number of non-binding guidelines on ewaste management that are continuously being developed by experts within the framework of the Convention. ${ }^{9}$ Electronic equipment handling is very influential on the

Katharina Kummer Peiry, "The Practice of Shared Responsibility in relation to Transboundary Movement of Hazardous Waste and Chemical" SHARES Research Paper, No. 87,2006 , p. 6. environment and human's health, ITU is committed to addressing the problems that are caused by and related to e-waste. This can be done by developing standards, raising awareness, and working closely with the technology and information industry. ${ }^{10}$

ITU together with the United Nations (UN) are working together to create a mechanism that can solve problems of e-waste. This is based on the fact that one of the largest ewaste piles is generated by electronic devices that can drive the Information and Communication Technology (ICT) sector, such as computers, cellphones, screens, cables, and other related components. This made ITU issued a policy regarding electronic waste management, especially for electronic ICT devices. ITU's simple campaign is to implement the $4 R$ Method, namely reuse, recycle, and reduce and repair.

Until now, the campaign gave a positive impact on reducing e-waste in various countries. However, this does not necessarily solve the problem of e-waste, because this will also be based on the regulation of each country. Countries that do not have regulations on e-waste management will treat e-waste the same as other waste in general, whether it is disposed of directly to landfills, or recycled together with metal and plastic waste. This will have the potential to pollute the environment and be harmful to workers who do the recycle.

ITU's participation is also in line with one of the goals in the Sustainable Development Goals (SDGs), especially goal number 12 which focuses on sustainable production and consumption, as well as the realization of other goals. Based on this commitment, ITU has provided several recommendations and supplements related to electronic waste

10 International Telecomunication Union, "ITU Activities on E-Waste",

https://www.itu.int/en/action/climate/Pages/ewaste.as px. 
management, especially for communication devices.

At the COP-6, through Decision $\mathrm{VI} / 31$ the MPPI was established. This program is a partnership that encourages the formation of a sustainable cooperation program between the public and the private sector on the management of used mobile phones that are environmentally friendly. ${ }^{11}$

At the COP-9, launched a partnership program 2011 Partnership for Action on Computing Equipment (PACE) PACE. ${ }^{12}$ It is a public-private cross-sectoral partnership program under the Convention that provides a forum for dialogue and cooperation from stakeholders to address problems of e-waste, especially computer waste. This partnership is intended to improve environmentally friendly management for used computers by adapting the principles of social responsibility, sustainable development and the exchange of information on environmental development. ${ }^{13}$

Solving the E-waste Problem (StEP) is an international initiative created to develop solutions to solve problems associated with ewaste. Several leading manufacturers, recyclers, government agencies, NGOs and the UN are among its members. StEP encourages collaboration of all stakeholders connected to e-waste, by emphasizing a holistic, scientific but workable approach to the problem. The main objective of StEP is to realize SDGs12 which responds to sustainable production and consumption.

This global agenda sets out the common vision, goals and targets that ITU Member States will achieve by 2020 . These targets will be achieved in collaboration with stakeholders in the ICT ecosystem. With the adoption of the 2020 Connect Agenda, ITU

Basel Convention Secretariat, Ibid.

Katharina Kummer Peiry, loc.cit.

PACE Working Group, Basel Convention - Partnership for Action on Computing Equipment (PACE) Guidance Document on the Environmentally Sound Management of
Member States have committed to a transition to an informed society, empowered by an interconnected world, where the ICT field enables and accelerates socially, economically, and environmentally sustainable growth and development for all. One of the main goals of the Connect 2020 Agenda is sustainability. Within this specific target, target 3.2 of the Agenda focuses on addressing the problem of e-waste by reducing the volume of excessive e-waste by $50 \%$ by 2020 .

At the regional level, there is the Bamako Convention on the Ban on the Import into Africa and the Control of Transboundary Movement and Management of Hazardous Wastes within Africa (1991), Waigani Convention, South Pacific (1995), Waste Electrical and Electronic Equipment Directive 2002 (WEEE Directive 2002), The Restriction on Hazardous Substances Directive (RoHS Directive), Regulation (EC) No 1013/2006 of the European Parliament and of the Council on Shipments of Waste (2016), The Durban Declaration, Africa (2008), and The Libreville Declaration, Africa (2008).

Environmental pollution generated from el-waste and its management cannot be categorized as domestic but complex pollution because the pollution produced does not see national borders. This shows that international law needs to regulate this issue. In fact, until now there has been no specific and comprehensive regulation on ewaste.

Since the 6th COP in 2002, e-waste has been discussed, particularly regarding aspects of ESM, prevention of illegal traffic to developing countries, and building capacity around the world to better manage e-waste. ${ }^{14}$ Along with the periodic COP, several projects

\footnotetext{
Used and End-of-Life Computing Equipment, Geneva: Secretariat of Basel Convention, 2011, p. 8

14 Basel Convention, "E-waste Overview", http://www.basel.int/Implementation/Ewaste/Overview /tabid/4063/Default.aspx.
} 


\section{Regional (ASEAN) Law with Environmental Protection Approach}

regarding environmentally friendly electronic waste management were formed with the creation of the Nairobi Declaration on the Environmentally Sound Management of Electrical and Electronic Waste, cooperation in e-waste management with African ${ }^{15}$, Asia Pacific $^{16}$, and South America, partnerships with stakeholders regarding the handling of cellular phone waste ${ }^{17}$, computer equipment ${ }^{18}$, and even the creation of guidelines that were last discussed at the COP-13 Basel Convention in September $2017^{19}$, and several workshops held in several countries, especially the export destination countries for e- waste.

Apart from the Convention, regional regulations regarding cooperation in electronic waste management are also growing. Apart from the regional instruments that have been mentioned above, Association of SouthEast Asian Nations (ASEAN) has not had a regional regulation regarding e-waste management.

ASEAN countries are actually not the main destination for e-waste exports but it is a region with relatively high level of electronic use such as Brunei Darussalam, Singapore, Malaysia, and Thailand namely the countries that produce the highest e-waste in ASEAN. This is inversely proportional to the situation in Cambodia, Laos, Myanmar, and Vietnam which only produce almost $1 / 10$ of e-waste

15 Basel Convention, “Overview: The e-waste Africa programme is a comprehensive programme aiming to enhance the environmental governance of e-wastes and to create favorable social and economic conditions for partnerships and small businesses in the recycling sector in Africa",

http://www.basel.int/Implementation/Ewaste/Ewastein Africa/Overview/tabid/2546/Default.aspx.

16 Basel Convention, "E-waste Asia-Pacific region Project", http://www.basel.int/Implementation/Ewaste/EwasteAs iaPacificregionproject/tabid/4065/Default.aspx.

17 Basel Convention, "Mobile Phone Partnership Initiative (MPPI)",

http://www.basel.int/Implementation/TechnicalAssistan ce/Partnerships/MPPI/Overview/tabid/3268/Default.asp $\mathrm{x}$. compared to the four countries. However, this cannot be used as a reason for ASEAN to turn a blind eye to this matter, because the conditions and trends in the use of electronic devices that are increasing with relatively short usage times will increasingly affect the amount of electronic waste increase in ASEAN countries in the near future.

In regional arrangements, based on the ASEAN Strategic Plan on Environment, ewaste, although still included in the category of hazardous waste, is one of the main objects in the focus of the institutional framework at The ASEAN Ministerial Meeting on the Environment (AMME) in the ASEAN Senior Officials on the Environment (ASOEN). In the working group, 7 (seven) subsidiary bodies were formed, one of which is the ASEAN Working Group on Chemicals and Waste (AWGCW) to discuss this issue. ${ }^{20}$ The agency seeks to establish an effective and fully functional regional mechanism to tackle transboundary movement of hazardous waste, including illegal traffic in accordance with the Procedures in the Basel Convention. ${ }^{21}$

Regulations regarding e-waste management in ASEAN need to be realized considering that ASEAN is one of the most developed regional regions, both in terms of resources and economy. Moreover, due to environmental cases that currently occur

18 Basel Convention, "Partnership for Action on Computing Equipment (PACE)", http://www.basel.int/Implementation/TechnicalAssistan ce/Partnerships/PACE/Overview/tabid/3243/Default.asp $\mathrm{x}$.

19 Basel Convention, "Development of Technical Guidelines on e-waste", http://www.basel.int/Implementation/Ewaste/Technical Guidelines/DevelopmentofTGs/tabid/2377/Default.aspx.

20 ASEAN, "Cooperation on Environment: At A Glance", https://asean.org/wp-content/uploads/2018/02/50.December-2017-ASEAN-Cooperation-on-EnvironmentAt-A-Glance.pdf, p. 3.

21 ASEAN, "ASEAN Working Group on Multilateral Environmental Agreements (AWGMEA)", http://intl.denr.gov.ph/index.php/aseanenvironmentalgroups/asean-working-groups/article/7. 
cross-border, regional mechanisms need to be implemented because until now regional instruments can be more responsive in handling cases across regional borders.

\section{E-WASTE MANAGEMENT PROBLEMS}

Currently, e-waste is a type of waste whose growth rate continues to increase and is the highest compared to other types of waste. The amount of electronic waste has reached about $8 \%$ of the total amount of waste produced worldwide each year. ${ }^{22}$

The high growth of e-waste is triggered by the shorter lifespan of electronic devices. The rapid development of technology causes product life to become shorter. Once something is new, consumers want to replace it immediately because they feel the old product is out of date. For example, in 1992, the age of a PC (personal computer) product was still 4.5 years, the age of the product then became 3 years in 1999 and finally only 2 years in 2005. Apart from computers, the age of cellphones, televisions, refrigerators, tablet computers and laptops are also getting shorter. ${ }^{23}$

This high growth of e-waste is also triggered by the rapid growth of the electronic business. Lower prices for products have led to lower costs for replacing computers, cell phones and other electronic devices. Based on data, in 2018 there were 4.57 billion cellphone users and this will potentially increase to 4.68 billion users in 2019 and to 4.78 billion users in 2020 .

The large number of sales of electronic equipment in the world market has encouraged the increasing regeneration of electronic waste. According to estimates from

22 Elizabeth Noble, "E-waste Think Thank: Review and Synthesis", Canberra Environment and Sustainability Resource Center, 2008, p. 12.

23 Rolf Widmer (et.al), loc.cit.

24 Madeleine Cobbing, "Toxic Tech: Not in Our Backyard", Greenpeace International Amsterdam, 2008, p. 3. the UN for Environment Program (UNEP), 2050 million tons of e- waste are generated annually from all over the world. It is estimated that the volume of e-waste will continue to increase by 3-5 percent or three times faster than general waste. ${ }^{24}$ Meanwhile, the recyclability level is no more than 10 percent. ${ }^{25}$ The high growth of e-waste is further seen from the high amount of ewaste produced in both developed countries as producers and exporters of e-waste, such as the United States and European Union countries as well as developing countries in Asia and Africa.

Based on the UN data, the total e-waste generated in 2016 was 44.7 million Mt or the equivalent of $6.1 \mathrm{~kg} /$ person. Total e-waste will continue to increase by $3-4 \%$ annually in 2017-2021. ${ }^{26}$

E-waste is waste originating from damaged, used and no longer used electronic devices by the owner. E-waste can be namely as the residue of a certain business or activity, in the form of production activities and usage by the owner. As previously described, ewaste has special characteristics which make it different as any other general or hazardous waste. If a more hazardous waste is produced from industrial byproducts, then e-waste is generated from a process of using electronic devices that are damaged, used and no longer used by the user.

E-waste also contains valuable materials. The precious material contained in it is even greater than the precious materials found in nature. In addition, the growth rate is high and even the highest among other waste. Therefore, e-waste management cannot be equated with hazardous waste management in general. Even though there are similarities

\footnotetext{
25 Joseph Ladou and Sandra Lovegrove, "Export of Electronics Equipment Waste", International Journal of Occupational and Environmental Health", Vol. 14, 2008, p. 10.

$26 \quad$ E-Waste Global Monitor 2017, op.cit., p. 38.
} 
The Urgency of Electronic Waste Management Regulation in International and

Regional (ASEAN) Law with Environmental Protection Approach

in terms of the content of hazardous and toxic materials in them, electronic waste requires special management.

\section{THE URGENCY OF SPECIAL MECHANISMS RELATED TO ELECTRONIC WASTE MANAGEMENT REGULATION IN INTERNATIONAL LAW}

Based on the analysis of the problems regarding the handling and management of ewaste that have been discussed in the previous section, this section will convey that there is an urgency to create a special mechanism related to e-waste management. By connecting the theory of legal objectives, it will automatically mean that the direction of people's lives, which in this case the standard of living will be better because the e-waste management arrangements made will aim at good environmental management and prevent environmental damage due to ewaste management which contains dangerous components which handled without proper and correct procedures.

The regulations in Convention can be applied in regulating electronic waste, the following explains the comparison of the arrangements in the Convention and what should be regulated in the regulations in the future:

\begin{tabular}{|c|c|c|}
\hline $\begin{array}{l}\text { Regulatory } \\
\text { Aspects }\end{array}$ & $\begin{array}{c}\text { Availability of Existing Regulations } \\
\text { and Gudelines) }\end{array}$ & Regulatory Model Concept \\
\hline $\begin{array}{l}\text { Definition of E- } \\
\text { Waste }\end{array}$ & $\begin{array}{l}\text { Basel Action Network (BAN), WEE } \\
\text { Directive }\end{array}$ & $\begin{array}{lll}\text { Explained } & \text { completely } & \text { and } \\
\text { thoroughly } & & \end{array}$ \\
\hline $\begin{array}{l}\text { Categorization of } \\
\text { E-Waste }\end{array}$ & WEE Directive, ITU Monitor 2017 & $\begin{array}{l}\text { A uniform categorization of } \\
\text { electronic waste was created } \\
\text { (previously ununiformed) }\end{array}$ \\
\hline $\begin{array}{l}\text { Management } \\
\text { Method }\end{array}$ & $\begin{array}{l}\text { Guideline in MPPI } 2011 \text { (for mobile } \\
\text { phone) }\end{array}$ & $\begin{array}{l}\text { A general scheme is made that can } \\
\text { be used as a direction, but will be } \\
\text { developed project by project per } \\
\text { category of e-waste }\end{array}$ \\
\hline $\begin{array}{l}\text { E-Waste Import/ } \\
\text { Export } \\
\text { Restrictions }\end{array}$ & $\begin{array}{l}\text { The Convention, BAN Amandement } \\
\text { (for hazardous waste) }\end{array}$ & $\begin{array}{l}\text { A limitation on the export and } \\
\text { import of e-waste is made which } \\
\text { can refer to the relevant provisions } \\
\text { in the Convention }\end{array}$ \\
\hline $\begin{array}{l}\text { Responsibility and } \\
\text { Compensation }\end{array}$ & $\begin{array}{l}\text { The Basel Protocol on Liability and } \\
\text { Compensation (for hazardous } \\
\text { waste) }\end{array}$ & $\begin{array}{l}\text { Regulation referred to Basel } \\
\text { Protocol }\end{array}$ \\
\hline ESM Management & $\begin{array}{l}\text { Basel Declaration on } \\
\text { Environmentally Sound } \\
\text { Management, RoHS Directive }\end{array}$ & $\begin{array}{l}\text { The implementation of ESM } \\
\text { management is regulated as one of } \\
\text { the main principles of } \\
\text { management }\end{array}$ \\
\hline $\begin{array}{l}\text { Minimization of } \\
\text { waste producing }\end{array}$ & $\begin{array}{l}\text { The Convention, Cartagena } \\
\text { Declaration 2011, ITU 4R's } \\
\text { Campaign, WEE Directive }\end{array}$ & $\begin{array}{l}\text { The concept of minimizing waste } \\
\text { production is regulated as one of } \\
\text { the main principles of } \\
\text { management enhanced by } \\
\text { optimizing the life cycle of } \\
\text { electronic equipment devices }\end{array}$ \\
\hline
\end{tabular}




\begin{tabular}{|l|l|l|}
\hline $\begin{array}{l}\text { Implementation } \\
\text { of EPR Principle }\end{array}$ & $\begin{array}{l}\text { ITU Recommendations, WEE } \\
\text { Directive }\end{array}$ & $\begin{array}{l}\text { The implementation of EPR } \\
\text { principles is regulated as one of the } \\
\text { main principles of management }\end{array}$ \\
\hline $\begin{array}{l}\text { Sustainable } \\
\text { Development }\end{array}$ & $\begin{array}{l}\text { Guidelines in Connect 2020 Agenda } \\
\text { for Global Telecommunication (for } \\
\text { mobile electronic devices) }\end{array}$ & $\begin{array}{l}\text { Regulated application of the } \\
\text { concept of sustainable } \\
\text { management as the main concept } \\
\text { of management }\end{array}$ \\
\hline $\begin{array}{l}\text { Green Business } \\
\text { health }\end{array}$ & \multicolumn{1}{|c|}{$\begin{array}{l}\text { Creation of a direction for } \\
\text { implementing ESM and } \\
\text { sustainable business } \\
\text { protection }\end{array}$} & $\begin{array}{l}\text { Environmental protection is the } \\
\text { main benchmark in regulations } \\
\text { and the concept of health } \\
\text { protection will be emphasized in } \\
\text { regulations }\end{array}$ \\
\hline $\begin{array}{l}\text { Coordination of } \\
\text { stakeholders }\end{array}$ & $\begin{array}{l}\text { Coordination will be one of the } \\
\text { recommended aspects in creating } \\
\text { a good and optimal e-waste } \\
\text { management mechanism }\end{array}$ \\
\hline
\end{tabular}

In practice, the mechanism regarding ewaste management can be specifically regulated under the Convention which has comprehensively regulated the transfer of hazardous waste along with other related special arrangements. This can also facilitate the integration of other supporting regulations related to electronic waste management that are linked to the Convention.

There are some basic aspects that can be developed in regulating e-waste management, including these following:

\section{Environmentally Friendly and Sustainable Business}

The UN has the potential to engage Member States through various forms of support and incentive strategies for more inclusive and socially sustainable business models to place more responsibility on the hands of electronics manufacturers. This includes providing support for small and medium enterprises in the development of reuse, repair, and recycle activities and for producers to implement return schemes (return or trade in) into their business activities.

In addition to supporting new businesses to be reused, repaired and refurbished, the UN system could consider supporting Member States and relevant Ministries in tracking and hazardous metal components used in electronic equipment. The development of reuse, repair and refurbishment services can provide opportunities to turn electronic equipment into waste, by re-engineering these metals into new products. Likewise, UN system support could seek to build an understanding of the existing industry around the relationship between e-waste and natural resource exploitation.

A stronger emphasis on the electronic appliance design phase will require stronger collaboration with the private sector and offer stronger opportunities for partnerships with the private sector that can work with entities under the UN. Moreover, regardless of the current legal conditions, the successful implementation of the integrated SDGs requires a bigger 
approach; for example, related to the supply chain and the production of electronic equipment. This must be done by not only placing an emphasis on the production supply chain, but also on increasing the level of e-waste collection in countries that have so far been small concern.

International cooperation and the role of the UN to promote the issue and management of relevant e-waste to member countries must be carried out. This can be done by expanding national data collection and information sharing, for example on the flow and characteristics of national e-waste; as well as developing and sharing good and bad ewaste management practices.

With international support related to measuring the amount, flow, and impact of e-waste appropriately at the level of each country, countries (especially those that do not have regulations related to ewaste management beforehand) can increase the knowledge of these countries about their e-waste management situation and lay the groundwork for suitable domestic countermeasures. In particular, through this type of support, a key component in overcoming the problem of e-waste, which includes strengthening waste and e-waste regulations and establishing an e-waste management system at the national level. In addition, improving the solid waste management system is also very important. In some cases, solid waste management systems are available but only consist of primitive strategies and run on household waste flows and pay less attention to e-waste management, so this system is still not optimal.

27 Dejo Olowu, "Menace of W-wastes in Developing Countries: An Agenda for Legal and Policy Responses",
E-waste management that is made is not only limited to entities that focus on issues related to the environment and waste management, but also includes factors such as labor, human health, and others. Consequently, by looking at ewaste from a life cycle perspective, the scope of the factors involved is enormous, and the many approaches needed to contribute to sustainable solutions become clear.

\section{Export and Import of E-Wastes}

Illegal export and import of e-waste was a problem that could often be found in various parts of the world. The approval of the two countries is needed so that the transfer of e-waste can be carried out properly and not be detrimental, especially to importing countries. However, in practice similar regulations have been regulated in the Convention but in practice this clause is the clause that is most often violated.

One of the efforts to reduce the practice of e-waste export and import is to anticipate that developed countries do not export to developing countries to avoid the responsibility for managing e-waste in their countries at a relatively much higher cost compared to exporting to developing countries is the implementation tax on imports of e-waste in the recipient country. ${ }^{27}$ This is to pressure the state to optimize and establish adequate e-waste management in the country, and if exports are carried out, at least this is done more responsibly and not detrimental to the receiving country with import duties as compensation for e-waste management.

This is not a legalization of the practice of exporting el-waste to developing countries, but is an alternative that can be

Law Environment and Development Journal, Volume 8, No. 1, p. 74. 
applied to see the reuse of used electronic devices, recycling, sorting, and management of e-waste (informal sector) is widely practiced in developing countries and has become the eye of people's livelihoods. The export destination country must also be accompanied by the condition that the receiving country has the capacity to manage certain e-waste according to its category, pay attention to and apply the maximum limit of the waste quota that the receiving country can accommodate and the application of the principle of transparency between countries sending and receiving the implementation of export-import and its management can run optimally. ${ }^{28}$

Another policy that needs to be implemented in this export and import is a more stringent categorization of electronic devices, namely by evaluating and checking "near the end of the life circle" so that goods that will enter can be categorized as used materials that can be reused or can be directly categorized as ewaste so that the control and supervision can identify what types of management can be carried out. ${ }^{29}$

\section{Extender Producer Responsibility Principle Approach}

More than 20 UN entities and 150 initiatives globally are active on handling e-waste. The scope of this initiative is very broad, from policy development, statistical work and training to designing the hazardous elements of products. From a regional perspective, most e-waste management initiatives are carried out with a focus on the African and Asian regions; inversely with a focus on the region of Europe, North America, Australia and New Zealand.

Sandra Alvarado Barrero, "Guidelines for the definition of a legal framework on electronic waste fron ICT", ITU, Geneva, 2017, p. 32, https://www.itu.int/en/ITU-
Since 2014, the Latin American and Caribbean regions have received more development assistance in the field of ewaste. The Asian and African regions are receiving more focus as a result of the curative nature of many of the current approaches to e-waste management. The current focus of the UN is largely on primitive and often abusive recycling practices, which are not environmentally friendly due to negative externalities arising from emissions entering land, water and air, and waste of resources and damage to workers' health.

Analyzing the entire electronic equipment life cycle from design and production to final disposal, most of the initiatives aimed at addressing e-waste focus on end-of-life treatment through the recycling and final disposal stages. Insufficient attention is paid to sourcing of raw materials, design and production, and repair, reuse, and repair of electronic equipment. However, this is not due to a lack of interest in this phase, but can be traced to the complex structure of stakeholders and business interests around the e-waste management area; and lack of attention to the life cycle of electronic equipment by sector specific stakeholders.

Currently, the need to address the lifecycle of manufactured electronics, including related issues such as product lifespan and consumer use, government and manufacturers' incentives to engage in extended producer responsibility (EPR) legislation still needs to emphasize the need for EPR schemes to be supported by national legislation and punitive measures, while overcoming the challenge of finding economically attractive business incentives and schemes.

D/Regional-Presence/ArabStates/Documents/Reports/EWASTE_LEGAL_FRAMEWORK_ITU.pdf.

29 Ibid., p. 32-33. 
Much of the responsibility lies with electronic equipment manufacturers in extending the life cycle of the products they sell, and in addition, extending their business responsibilities beyond the enduse limits of consumers. At the same time, choosing the latest technology and the latest fashions at the lowest possible price remains ingrained in the behavior of many consumers, impacting the reparability of many products and therefore also contributing to the growing numbers of ewaste.

In practice, the application of EPR principles has been effectively carried out in European Union countries and can run effectively with the support of related regulations and compliance with member countries to implement a waste management system based on EPR principles. ${ }^{30}$ In the Asian region, Japan, South Korea and Taiwan are the pioneers of leading countries with the concept of managing electronic space according to the application of EPR principles, followed by developing countries such as China and Thailand which have also begun to adapt this principle. ${ }^{31}$

One of the obstacles in the application of EPR principles is the additional costs that must be incurred by manufacturers to monitor e-waste management for each electronic device produced. Basically, producers must collect e- waste that is produced using certain collection mechanisms or that have been integrated with the government, but there is also a practice when producers have to buy it from e-waste sellers. This makes it difficult to apply the same principles of EPR

30 Ch. Stiglitz, "The Role of Extended Producer esponsibility in Strategic Waste Management", paper, http://ewit.site/wp-content/uploads/2017/01/EPR-inWaste-Management.pdf.

31 Sung-Woo Chung, Rie Murakami-Suzuki, "A Comparative Study of E-waste Recycling Systems in Japan, South Korea because not all producers can carry out the same capacity in handling e-waste they produce. Regional factors are also a major factor in whether the EPR can be implemented properly or vice versa. ${ }^{32}$

In practice in Japan, South Korea and Taiwan, producers have an obligation to manage e-waste at a cost borne by the producer, but on the other hand, consumers also have an obligation to pay for the waste handling fee, at least for transportation to the waste management site so that the synergy of applying the principle EPR and the management and recycling process work well. This shows that the EPR principle cannot run perfectly if there is no willingness from the consumer and cooperation is needed in its application.

4. Optimization of Electronic Equipment Life Cycle for Sustainable Production and Use The principle of sustainable production and use is in line with Target 12 of the SDGs, which promotes sustainable use and production. Responsible consumption and production are linked in two ways: increased dematerialization and virtualization and innovative ICT applications that enable sustainable production and consumption. This can be applied to the use of integrated technology and to reduce the energy consumption of electronic devices which has a positive impact on reducing consumption in general. However, the use of these electronic devices requires energy consumption. Therefore, an effective policy is needed to ensure that negative impacts such as e-waste are minimized.

and Taiwan from the EPR Perspective: Implications for Developing Countries", in Michikazu Kojima ed., Promoting 3Rs in Developing Countries: Lessons fron Japanese Experience, Chiba: IDE-JETRO, 2008, p. 127. Ibid. 
This can be done by producing sustainable products for producers and becoming smart and environmentally friendly consumers.

Sustainable production can be done by doing clean production and considering the full life cycle of electrical and electronic equipment needs to be done. Manufacturers should pay attention to the early stages of the life cycle such as design and production while at the same time ensuring that all stages are considered from design, use, to final disposal. The ideal electronic equipment model can make use of it more optimally and last a long time so that it will minimize the ewaste that will be generated. However, other problems such as the reluctance of manufacturers to do this because durable electronic equipment will reduce sales and profits. Therefore, it is necessary to have other cooperation mechanisms such as providing incentives to producers or raising standards for components in electronic equipment so that their life cycle can be optimized.

On the other hand, consumers must also be able to become smart consumers in choosing goods that are environmental and consumption friendly, sustainable, long-term use and responsible for the waste generated at the time of disposal. Apart from requiring awareness from consumers, this must also be supported by the participation of the government. The government must promote environmentally friendly movements and educate people to be more sensitive to the environment.

The most common e-waste management practices in developing countries today are open disposal or use of other chemical processes such as acid baths and incorporation to separate valuable components in e-waste. During the production of electronic equipment, there was little attention paid to ecofriendly designs that implied products' life cycle.

Electronic equipment still contains hazardous chemicals such as mercury or lead which makes it still impossible to increase the product life span. Currently, the use of some of these chemicals has begun to be implemented, there are substitutes (alternatives) that are not dangerous, but this has not been able to reach all the chemical components used in the production of electronic equipment.

By designing electronic equipment with easily separable components, recycled metals and harmless metals, it will be possible to prevent the build-up of waste at the end of its life. Manufacturers should be able to move from using less durable components to more durable components. Manufacturers should also be encouraged to design products that are easy to repair and have easy-to-find spare materials. In addition, recycling and reuse will be easier to achieve if the manufacturers apply the principle EPR.

\section{Protection of Environment and Health}

The problems associated with e-waste are very complex to handle because of their composition which is full of toxic chemicals. Most of these substances are known to cause serious human health problems and need to be handled with great care to avoid adverse effects. The appropriate technology is needed for handling chemicals contained in e-waste. Although some of these materials are used in small amounts, the recycled volume aggregate is very important and can have serious impacts on the environment and human health if not handled by the adequate procedures and facilities which until recently are still practiced in many parts of the world. Some of these processes involve direct burning or 
heating, use of acid baths, incorporation of mercury and other chemical processes to recover metal materials. This process results in the release of toxic materials into the environment through emissions or waste. $^{33}$

This shows that the main factor that makes electronic waste dangerous to the environment is the hazardous material or metal content in it. In addition to the need for good management processes so as to minimize threats to the environment resulting from inappropriate dumping and management, alternatives to the use of substances that are more environmentally friendly can be made and can simplify the flow of e-waste management.

In addition, at landfills, a nonbiodegradable waste and left for a long time becomes a source of contaminated leachate which can contaminate groundwater as well as drinking water supplies. Acid and sludge obtained from melting computer chips causes soil acidification. Non-degraded and toxic, pollutants can enter the biological food chain by absorption from plant roots through contamination of soil and groundwater. Bioaccumulation of heavy metals and other organic pollutants is a big threat to the life of higher animals and humans. ${ }^{34}$ This illustrates that in addition to the harmful effects that can occur due to the direct activities of workers when recycling and managing e-waste without using certain procedures, neglect of untreated e-waste piles, especially outdoor storage, can endanger the soil and water supply, resulting in dangerous metal content that might be consumed by the surrounding community.

33 Raaz K Maheshwari, (et.al.), “Dribble of E-Waste: It's Impact on Human Health \& Management Strategies for

\section{Collaboration and Coordination between States and Stakeholders}

Collaboration and coordination between countries and other stakeholders needs to be done so that the goal of efficient and effective e-waste management can be realized. Although there are many activities carried out by the UN to overcome the challenges of e-waste management, these have not been carried out optimally, moreover, they are not accompanied by regulations in international law that specifically regulate collaboration and coordination in e-waste management between stakeholders. With the increasing number of collaborations being carried out, stakeholders can come together to reach solutions for sustainable e-waste management.

\section{E. APPLICATION OF INTERNATIONAL E- WASTE MANAGEMENT ARRANGEMENTS IN ASEAN}

Several other regional areas have regional regulations regarding waste management such as the European Union, Africa and the Pacific. Implementation in the European Union has gone well because it is supported by a series of regulations related to e-waste management and the application of EPR principles. Apart from the European Union, the African Union also has the Bamako Convention which regulates e-waste management in the African region. However, this instrument was less successful in being applied and became a guide for regional ewaste management and eradicating the practice of importing electronic waste to Africa. Even now, only half of the African Union countries have ratified the Bamako Convention. Apart from the Bamako Convention, countries in the Pacific are also

Sustainable Development", Research Journal of Chemical and Environmental Sciences, Vol. 1, No. 2, 2013, p. 13-14. $34 \quad$ lbid., p. 6. 
trying to make regional regulations regarding electronic waste, namely the Waigani Convention, but in reality this regulation has also failed to apply. Looking at these, it some regions have not been able to implement regulations effectively due to certain inhibiting factors. This needs to be considered by ASEAN in planning regional regulations related to el-waste management so that in the future the implementation of regulations can be carried out and not merely become ineffective regulations.

Currently in other regional areas, ASEAN, have started to pay attention to the problem of e-waste. This can be seen from the commitment of ASEAN and its member countries to create an "ASEAN Cooperation on Environment", one of which focuses on the problem of chemical substances (particularly those that are hazardous and waste in a comprehensive manner). One of the work focuses on this cooperation is on e-waste management in ASEAN along with the export and import of e-waste in ASEAN countries. This concern regarding electronic waste is very much heeded in the ASEAN forum because waste management is still wrong and unsafe and can endanger human health and the environment. The high waste growth rate in ASEAN countries is also very high, which is $63 \%$. In 2014, it was recorded that each person produced $4.64 \mathrm{~kg}$ of waste per person/year. This data is recorded to be greater than the average for Asian countries which is only $3.7 \mathrm{~kg}$ of waste per person/year and in Africa, it is $1.7 \mathrm{~kg}$ of waste per person/year. ${ }^{35}$

Furthermore, ASEAN's commitment is contained in the ASEAN Environmental Education Action Plan 2014-2018 which

\footnotetext{
35 ASEAN Cooperation on Environment, "ASEAN Cooperation on Chemicals and Waste", https://environment.asean.org/awgcw/.

36 ASEAN Cooperation on Environment, "ASEAN Cooperation on Chemicals and Waste", https://environment.asean.org/awgcw/.
}

educates stakeholders about the importance of maintaining a clean and green environment for ASEAN, by providing education on environmental insights based on the principles of sustainable development. ${ }^{36}$ This also means that the handling of e-waste management in ASEAN countries and/or cross-border needs to be paid more attention to seeing that the cross-border movement of e-waste in ASEAN countries is getting higher.

The large volume of e-waste generated by ASEAN countries is quite large and this is reversed with the per capita income of ASEAN countries which tends to be small. In fact, many people in ASEAN countries buy used electronic devices at affordable prices. The opening of factories that produce electronic equipment in ASEAN countries also plays an important role in increasing the high number of e-waste production in ASEAN. ${ }^{37}$

The high production of e-waste is in line with the increasing opportunities and needs for recycling of e-waste, both formally and informally. However, the high demand and practice of re-leafing e-waste is not comparable with regulations related to ewaste management in these countries. ${ }^{38}$

Moreover, there is a policy from China that has begun to ban imports of waste, one of which is electronic waste and this commitment will be carried out $100 \%$ in 2020 which will more or less have an impact on the rhythm of e-waste imports to ASEAN countries. As is well known, although ASEAN countries are not destination countries for ewaste imports, in practice several countries in ASEAN have become destination countries. Some examples are Singapore, which is not the final destination country for e-waste imports, but Singapore is a transit country

37 Suichi Honda, (et.al.), "Regional E-waste Monitor: East and Southeast Asia", United Nations University \& Japanese Ministry of the Environment, 2016, p. 34.

$38 \quad$ Ibid. 


\section{Regional (ASEAN) Law with Environmental Protection Approach}

until it ends up in other ASEAN countries. Thailand, Laos and Cambodia are also new ewaste import destinations after China closed the waste import route to its country, which incidentally received $70 \%$ of the total e-waste imports.

Another reason that can make it easier for developed countries to import e-waste to ASEAN countries is the existence of a market for buying and selling used electronic goods, refurbished (renewed) used goods, or electronic equipment that is no longer functioning, some of its components can still be taken for other electronic goods. This makes the import of e-waste one of the profitable commodities in ASEAN countries because these electronic devices can not only be referred to as waste. This can create loopholes for e-waste smuggling due to different perceptions of what constitutes ewaste.

In addition, the uneven knowledge of the public in ASEAN countries regarding the dangers of e-waste and its different characteristics from other conventional waste is also one of the more difficult factors in implementing policies on e-waste directly and comprehensively in ASEAN countries. Moreover, apart from being the destination for importing e-waste, ASEAN countries are also the locations for factories for the world's electronic brands, although this is not the case in all countries. Electronic equipment such as televisions, radios, computers and cell phones originate from the ASEAN region.

More than $80 \%$ of hard drives supplied worldwide are made in ASEAN. Thailand is Southeast Asia's largest electronics assembly country with more than 2,300 companies supported by 400,000 employees. The producers in Thailand are multinational companies from Europe, the United States, Japan and South Korea. Indonesia is also a factory for several multinational electronic brands apart from Indonesia which owns several local electronic brands in its country. Vietnam and Myanmar are currently also increasingly moving to become producing countries that are able to compete with other ASEAN countries with more competitive production costs and cheaper labor wages. ${ }^{39}$

The concept of implementing regional mechanisms regarding e-waste management in ASEAN can be carried out by taking into account the following aspects:

a. creating a framework and basis for developing/harmonizing appropriate legislation, in the form of rules or guidelines on e-waste management;

b. establishing appropriate strategies for End of Life (EoL) management of electronic equipment;

c. implementing effective public awareness mechanisms on issues related to e-waste and its management; and

d. creating and enabling an environment for the promotion of public and private investment in e-waste management.

Regarding the EoL management strategy of electronic equipment, ASEAN countries have the habit of using used equipment, repairing it, even carrying out upcycle (reuse by producing goods with better/higher quality) existing e-waste or that enter their country. Vietnam for example, has revised its Environmental Protection to include producer financial responsibility for collection of EoL Products. Therefore, this habit can be used as a local principle that can be applied in ASEAN regional regulations regarding the use of ewaste, namely waste from the use of electronic devices can be reused or converted into new products or components to support new products before eventually becoming waste that cannot be utilized. However, this does not mean that ASEAN countries can

39 Invest in ASEAN, "Electronics: Ehere to invest?", http://investasean.asean.org/index.php/page/view/elec tronics. 
accept e-waste imports from developed countries.

Regarding the application of the EPR concept, in the last few years, efforts to handle electronic waste have begun to see the increasing number of electronic waste produced and its impact on the environment. In addressing environmental challenges, the EPR concept has received increasing interest. This concept represents an environmental protection concept that makes product manufacturers responsible for the entire life cycle of their factories, including the postconsumption phase.

This concept was adopted by the European Union which adopted two directives with the aim of addressing the problem of e-waste, which are applied in the WEEE-Directive 2002/96 and RoHS-Directive 2002/96. The WEEE regulations aim to reduce concerns about waste management, while the EU RoHS limits the use of hazardous substances contained in electronic equipment. The ban on the six hazardous substances aims to prevent contamination from hazardous substances due to improper treatment or disposal. Only products that meet the requirements can be permitted for sale on the EU market.

The implementation of the directive has also triggered a reconsideration of policies regarding e-waste management among nonEU countries, particularly in countries that have close trade relations with the European Union. ${ }^{40}$ In general, the EPR concept has caught the attention of policy makers in Asia. Thailand, for example, has responded with national legislation with the same goal

40 A. Ibitz, "A Trade and the Environment: The Influence of the European Union's Environmental Directives on China", Issues \& Studies, Vol. 45, No. 3, 2009, p. 165-209.

41 C. Tingsabadh and P. Jantarasarsophon, "Electrical and Electronic Equipment - Environmental impacts of trade liberalization. International Institute for Sustainable Development", 2007, http://www.iisd.org/pdf/2007/rtea_thai_electrical.pdf.
("Thailand RoHS"). ${ }^{41}$ However, due to trade variations, not all ASEAN member countries feel the same pressure to respond. In 2005, Thailand issued a bill aimed at tackling the flow of e-waste. This regulation can be seen as a direct response to the EU WEEEDirective. Thailand has adopted regulations that shift financial responsibility for recycling e-waste. The overall policy includes measures that require manufacturers of electrical and electronic equipment to use a certain minimum level of recycled input. ${ }^{42}$

The application of the EPR concept is one solution to reduce the proliferation of ewaste production. By placing the responsibility on the producer, waste handling and management can be reused into new, similar goods or can pressure producers to produce goods that are more environmentally friendly, have a longer life cycle and are sustainable which will make it easier for producers to handle the waste produced. The EPR concept can also be found in the Indonesian Law on Waste Management in 2008, where producers were given more responsibility to transact with EoL products..$^{43}$

As for Malaysia, the Solid Waste Management Act 2007 and Public Waste allows the government to take responsibility for the collection of products by manufacturers, fabricators and importers. There is hope that in the long term, such environmental considerations can spread to several other ASEAN countries.

However, the implementation of EPR is likely to be difficult to be implemented optimally in developing countries such as the ASEAN region. This is because e-waste

42 P. Manomaivibool and S. Vassanadumrongdee "Extended Producer Responsibility in Thailand Prospects for Policies on Waste Electrical and Electronic Equipment", Journal of Industrial Ecology, Vol. 15, No. 2, 2011, p. 185-205.

43 Saputra, "People's Legislative Assembly Passes Law on Rubbish Management, Voice of Human Rights", 2008, http://www.vhrmedia.com/ inggris/vhr-news/beritadetail.php?.g=news\&.s=berita\&.e $=50$ 


\section{Regional (ASEAN) Law with Environmental Protection Approach}

management is still monopolized by the informal sector. Formal sector e-waste managers must comply with the standards of certain types of environment and follow labor protection measures, while the informal sector often neglects rules and safety in carrying out management to reduce costs.

In addition, the implementation of EPR faces difficulties as it is often not easy to identify producers or importers. For products assembled by small businesses, it is difficult to place the responsibility on the manufacturer. In the case of contraband or product imitations, it is less likely to apply this approach. Against the background of the high rate of smuggling and imitated equipment in the region, the implementation of the EPRbased law has not been fully implemented.

Regarding the export and import activities of electronic waste, it cannot be denied that ASEAN countries are new import destinations so this aspect also needs to be regulated in regional arrangements between the existence of an agreement to reject all kinds of imports of e-waste but still allow goods with good value/useful components as will be implemented by China in 2020, allowing on the condition of importing e-waste because it cannot be denied that e-waste is a commodity that can be utilized properly by several parties in several countries or apply other mechanisms.

In implementing regulation formation, ASEAN is an association that tends to be passive in making related arrangements needed in the ASEAN region. Based on its habits, ASEAN is very interested in creating forums under it regarding the environment but in its implementation these forums do not make a real contribution in the formation of regulations or directives on environmental issues faced by ASEAN countries, so in practice at this time There are no concrete regulations made by the forum under the association related to e-waste and the management and cooperation of export and import within the region. ASEAN still tends to respond responsively to issues after a case occurs rather than providing direction as a preventive measure.

Furthermore, the character of ASEAN which is a cooperative institution also makes it difficult to make e-waste regulations. Based on a track record of handling issues that occur in the region, ASEAN often makes guidelines or guidelines that are easier to apply because they are in the form of directions rather than rigid rules. Therefore, the form of establishing a regulatory mechanism for e-waste management in the ASEAN region can be made in the form of directives or guidelines.

\section{F. CONCLUSION}

International legal regulations regarding ewaste management that are specific and comprehensive have not been available, however the transfer of hazardous waste between countries has been carried out with reference to the regulations in the Basel Convention 1989. In its development, the international community has created several working groups to form a specified international legal instrument. The urgency regarding the establishment of a regulatory mechanism for electronic waste management in international law must immediately be realized. One of them is by creating a mechanism under the Basel Convention. The creation of a mechanism under the Convention to integrate with other relevant existing regulations. This mechanism must also be created by prioritizing environmental and sustainable aspects of e-waste management.

This can be carried out by creating a mechanism under the Convention which has the principle of sustainable development in which management responsibility is emphasized on the responsibility of producers from the start of production to the end of e-waste management; implementing 
an environmentally friendly and sustainable business; Arrangement of policies for the export and import of e-waste between countries; and collaboration and coordination between countries and other stakeholders. To anticipate the activities of moving e-waste from developed or producing countries, a financing scheme for the development and management of electronic waste can be applied in destination countries as an extension of the responsibility of producers.

The application of the ASEAN regional electronic waste management regulation can be carried out by referring to the mechanisms applied in national law, in its application the character of ASEAN is a cooperative institution which in its development often creates guidelines or guidelines that are easier to apply because of their form in the form of directions compared to regulations is rigid in nature so that the form of a regulatory mechanism for e-waste management in the ASEAN region can be made in the form of directives or guidelines.

\section{REFERENCES}

\section{Books}

Baldé, C.P., (et.al.), The Global E-waste Monitor - 2017, United Nations University (UNU), International Telecommunication Union (ITU) \& International Solid Waste Association (ISWA), 2017.

Birnie, Patricia W. (et.al), International Law and the Environment, Oxford University Press, Oxford, 2008.

Honda, Suichi, (et.al.), Regional E-waste Monitor: East and Southeast Asia, United Nations University \& Japanese Ministry of the Environment, 2016.

Kojima, Michikazu, (ed.), Promoting $3 R s$ in Developing Countries: Lessons fron Japanese Experience, IDE-JETRO, Chiba, 2008.
M. Daud Silalahi, Hukum Lingkungan dalam Sistem Penegakan Hukum Lingkungan Indonesia, Alumni, Bandung, 2001.

Otto Soemarwoto, Ekologi, Lingkungan Hidup dan Pembangunan, Djambatan, Jakarta, 1991.

\section{Other Documents}

ASEAN Cooperation on Environment, "ASEAN Cooperation on Chemicals and Waste", https://environment.asean.org/awgcw/.

ASEAN, "ASEAN Working Group on Multilateral Environmental Agreements (AWGMEA)", http://intl.denr.gov.ph/index.php/aseanenvironmental-groups/asean-workinggroups/article/7.

ASEAN, "Cooperation on Environment: At A Glance", $\quad$ https://asean.org/wpcontent/uploads/2018/02/50.December-2017-ASEAN-Cooperation-onEnvironment-At-A-Glance.pdf.

Barrero, Sandra Alvarado, "Guidelines for the definition of a legal framework on electronic waste fron ICT", ITU, Geneva, 2017, https://www.itu.int/en/ITUD/Regional-

Presence/ArabStates/Documents/Report s/E-

WASTE LEGAL FRAMEWORK ITU.pdf.

Basel Convention, "Development of Technical Guidelines on e-waste", http://www.basel.int/Implementation/E waste/TechnicalGuidelines/Development ofTGs/tabid/2377/Default.aspx.

Basel Convention, "E-waste Asia-Pacific region Project", http://www.basel.int/Implementation/E waste/EwasteAsiaPacificregionproject/ta bid/4065/Default.aspx.

Basel Convention, "E-waste Overview", http://www.basel.int/Implementation/E waste/Overview/tabid/4063/Default.asp $\underline{x}$

Basel Convention, "Mobile Phone Partnership Initiative (MPPI)", http://www.basel.int/Implementation/T 
The Urgency of Electronic Waste Management Regulation in International and

Regional (ASEAN) Law with Environmental Protection Approach

echnicalAssistance/Partnerships/MPPI/O verview/tabid/3268/Default.aspx.

Basel Convention, "Overview: The e-waste Africa programme is a comprehensive programme aiming to enhance the environmental governance of e-wastes and to create favorable social and economic conditions for partnerships and small businesses in the recycling sector in Africa", http://www.basel.int/Implementation/E waste/EwasteinAfrica/Overview/tabid/2 546/Default.aspx.

Basel Convention, "Partnership for Action on Computing Equipment (PACE)", http://www.basel.int/Implementation/T echnicalAssistance/Partnerships/PACE/O verview/tabid/3243/Default.aspx.

Cobbing, Madeleine, "Toxic Tech: Not in Our Backyard", Greenpeace International Amsterdam, 2008.

Heacock, Michelle, et.all., "E-Waste and Harm to Vulnerable Populations: A Growing Global Problem", Environmental Health Perspective, Volume 124, Issue 5, 2016.

Ibitz, A., "A Trade and the Environment: The Influence of the European Union's Environmental Directives on China, Issues \& Studies, Volume 45, Issue 3, 2009.

International Telecomunication Union, "ITU Activities on E-Waste", https://www.itu.int/en/action/climate/P ages/ewaste.aspx.

Invest in ASEAN, "Electronics: Ehere to invest?", http://investasean.asean.org/index.php/ page/view/electronics

Ladou, Joseph, Sandra Lovegrove, "Export of Electronics Equipment Waste", International Journal of Occupational and Environmental Health", Volume 14, 2008. Maheshwari, Raaz K., Bina Rani, Upma Singh, "Dribble of E-Waste: It's Impact on Human Health \& Management Strategies for Sustainable Development", Research
Journal of Chemical and Environmental Sciences, Volume 1, Issue 2, 2013.

Manomaivibool, P., \& Vassanadumrongdee, S., "Extended Producer Responsibility in Thailand Prospects for Policies on Waste Electrical and Electronic Equipment", Journal of Industrial Ecology, Volume 15, Issue 2, 2011.

Elizabeth Noble, E-waste Think Thank: Review and Synthesis, Canberra Environment and Sustainability Resource Center, Canberra, 2008.

Olowu, Dejo, "Menace of W-wastes in Developing Countries: An Agenda for Legal and Policy Responses", Law Environment and Development Journal, Volume 8, Issue 1.

PACE Working Group, Basel ConventionPatnership for Action on Computing Equipment (PACE), Guidance Document on the Environmentally Sound Management of Used and End-of-Life Computing Equipment, Jenewa: Secretariat of Basel Convention, 2011.

Peiry, Katharina Kummer, "The Practice of Shared Responsibility in relation to Transboundary Movement of Hazardous Waste and Chemical" SHARES Research Paper, No. 87, 2006.

Saarikko, Ted, Ulrika H. Westergen, Thomas Blomquist, "The Internet of Things: Are you ready for what's coming?", Business Horizons, Volume 60, Issue 5, 2017.

Saputra, H., People's Legislative Assembly Passes Law on Rubbish Management. Voice of Human Rights, 2008, http://www.vhrmedia.com/inggris/vhrnews/beritadetail.php?.g=news\&.s=berita\&.e=50.

Stiglitz, Ch., "The Role of Extended Producer esponsibility in Strategic Waste Management", paper, http://ewit.site/wpcontent/uploads/2017/01/EPR-in-WasteManagement.pdf. 
Tingsabadh, C., \& Jantarasarsophon, P., Electrical and Electronic Equipment Environmental impacts of trade liberalization. International Institute for Sustainable Development, 2007, http://www.iisd.org/pdf/2007/rtea_thai_ electrical.pdf.

Widmer, Rolf (ed.), "Global Perspective on Ewaste", Environmental Impact Assessment Review, Volume 25, 2005. 